\title{
THE EFFECTS OF TRADITIONAL AND ALTERNATIVE ROUTES OF TEACHER CERTIFICATION ON STUDENT ACHIEVEMENT
}

\author{
Jenita C. Hegwood ${ }^{1 *}$ \\ *11Assistant Professor of Teacher Education Southern University at New Orleans
}

*Corresponding Author: -

\begin{abstract}
: -
The demand for accountability over the past decades has altered the landscape of educational success determinants. However, even before the beginning of the advocacy for accountability, various studies were focused on ways of improving test scores. The implementation of the No Child Left Behind Act has forced schools and institutions to look at programs to ensure the success and accountability of students at the elementary and high school level. Supporters of the No Child Left Behind Act believe the emphasis on test results will improve the academic success for all students (White, n.d.). Students are now tested every year to determine their progress from year to year. This helps parents, school leaders, and teachers measure teacher growth and student learning. This new assessment system in schools has resulted in teachers having to pay more attention to the requirements of a test and student achievement. States are now forced to produce effective and highly qualified teachers. One of the most critical factors affecting student achievement is the teacher. An effective teacher helps students outperform those students who are not served by an effective teacher (No Child Left Behind Toolkit for Teachers, 2004).
\end{abstract}

Keywords: - pedagogy, certification, teacher quality 
Traditionally most U.S. school districts have hired graduates that have completed a teacher preparation program from a college or university. Completion of traditional teacher preparation programs are the most common route to teacher certification. The traditional program is shaped by a combination of state regulations, the criteria of accreditation groups, and the choices made by institutions. Pre-service teachers who successfully complete the traditional program only need to pass required certification exam to become licensed. States assume that individuals who complete the state approved program have met the required course content and field experiences. Most traditional programs spend many hours on teaching pedagogy which include theories, exams, and classroom management (Boyd, Goldhaber, Lankford \& Wyckoff, 2007).

The declining number of available teachers, a concern of the quality of individuals entering the classrooms, and the need for schools to hire people with unique skills has increased the number of alternative certification programs across the U.S. (Bradshaw, 1998). Alternative programs are defined by the U.S. Department of Education as: "teacher preparation programs that enroll non-certified individuals with at least a bachelor's degree, offering shortcuts, special assistance, or unique curricula leading to eligibility for standard teaching credentials" (Bradshaw \& Hawk, 1996, p. 7). Some states like New Jersey, Texas, and California rely heavily on alternative routes of certification for their teacher supply.

The requirements of alternative route programs differ by state. Many programs have both pre service and in service requirements. Pre-service activities range from four to twelve weeks during the summer before the new teacher enters the classroom and often includes pedagogy methods of teaching and field experiences. In service preparation usually includes coursework and mentoring (Bradshaw, 1998).

\section{Statement of the Problem}

No Child Left Behind (NCLB) lays out several provisions regarding "highly qualified" teachers and provides a broad and seemingly simple definition of what constitutes a "highly qualified" teacher: Anyone with a bachelor's degree who has been certified as a teacher and can demonstrate content knowledge through coursework or testing is deemed "highly qualified" under the law. As the law stands, all states have to have their core subject classes taught by "highly qualified" teachers. On paper, states are given leeway to interpret how they will meet the federal standards for "highly qualified" teachers, but the reality is that states are being forced to substitute a federal definition of "highly qualified" for their own. To this end, each local educational agency (LEA) must develop a plan to ensure that all elementary, middle and high school teachers who are assigned to teach core academic subjects meet the NCLB requirements to ensure they are highly qualified (Au, 2004).

Arguments over alternative teacher certification vs. traditional teacher preparation have been heated. On one side, proponents view alternative certification as an effective way to put bright and talented individuals into classrooms without forcing them to jump the "meaningless hurdles" of traditional teacher preparation. They claim alternative certification will help diversify the teacher workforce, alleviate shortages in fields such as mathematics and science, and benefit students as teachers bring real-world experiences to the classroom. On the other side, opponents see alternative certification as a threat to teacher professionalism by allowing unprepared individuals into the classrooms. They claim that it offers teachers a lower quality preparation and is a disservice to students (Humphrey \& Wechsler, 2006).

\section{Significance of the Study}

As new standards for student learning have been introduced across the states, greater attention has been given to the role that teacher quality plays in student achievement. In the last few years, more than twenty-five states have enacted legislation to improve teacher recruitment, education, certification, or professional development. While some evidence suggests that better qualified teachers may make a difference for student learning at the classroom, school, and district levels, there has been little inquiry into the effects on achievement (Darling-Hammond, 2002). This article is likely to be of interest to local school districts and schools when looking for highly qualified and well prepared individuals to enter the classroom. One out of every five Texas public school teachers has gone through an alternative certification program. Research shows that alternative certified teachers are more likely to end up teaching children in high poverty schools. The State Board of Education (SBEC) is considering a new rule to only accept applicants who have a 2.5 grade point average or higher into alternative certification programs. Teachers in these programs would also be required to go through a set of required training hours before entering the classroom. Stricter regulations will improve teacher quality and student performance (Unmuth, 2008).

\section{LITERATURE REVIEW}

The past two decades have seen dramatic changes in the number of routes taken by prospective teachers to earn teaching certification. In the early 1980 s, only eight states offered what are commonly referred to as alternative routes for prospective teachers to obtain teacher certification. As of 2002, 45 states and the District of Columbia offered some type of alternative certification. By some estimates, about one-third of newly hired teachers come through alternative certification. The rapid change in methods of teacher certification has fueled a fierce debate over state teacher certification policy and its relationship to teacher quality (Feistritzer \& Chester, 2002). In the present paper, the traditional and alternative routes of certification are analyzed to see which route yields higher student achievement. The following three literature review attempt to demonstrate there is a significant difference between teacher preparation programs and student achievement.

In a research article by Mayer, Decker, Glazerman, and Silva (2003), revealed that when alternative and traditional routes of certification are placed side by side, they can be and analyzed as to which program yields higher student results. Presumably, teacher training policy should promote student academic success, but the existing literature on alternative 
certification and its effects on student learning are weak. Nor does the literature provide definite evidence about effective approaches to equip teachers for performing successfully in classrooms. The proponents of traditional certification view alternative certification as a threat to the quality of teachers and education. They view the process of becoming a qualified teacher as similar to the process of becoming a qualified doctor, lawyer, or architect and thus requiring several years of pre-service professional training before a teacher can take full responsibility for a classroom (Stoddart \& Floden, 1995). Darling-Hammond (1994) argues that creating alternative routes to certification permits unlicensed teachers into the classroom simply as a way to remedy teacher shortages, thereby reducing the overall quality of teaching. Echoing the argument that substantial training is required to become a qualified teacher, a commission of 23 leaders in education policy concluded the following: "A college major or minor, or professional experience in the field, guarantees neither a command of subject matter nor the ability to teach it successfully. The knowledge base of teaching is incomplete unless candidates master not just the what of course content, but also the how of teaching as well" (Darling-Hammond, 2002).

On the other side of the debate are those who support alternative certification. Initially, state legislatures created alternative certification routes to deal with teacher shortages in the areas of secondary mathematics and science. But because shortages persisted in other levels and content areas in some of the nation's rural and urban schools, states established alternative certification routes in elementary education, special education, and bilingual education. Those who support alternative certification as a means of redressing teacher shortages do not necessarily view alternative certification routes as desirable. In fact, many view alternative certification as a "last resort" to be used only when traditionally certified teachers are in short supply (Hawley, 1992). Indeed, some states make their alternative routes available to prospective teachers only in shortage areas. Some supporters of alternative certification believe, however, that alternative certification should be viewed as a first resort rather than as a last resort and that removing traditional certification barriers will expand and improve the labor pool by encouraging academically talented and ethnically diverse candidates to enter the profession (Hess, 2001; Kanstoroom \& Finn, 1999).

Next, the debate over alternative certification has fueled a variety of assumptions about participants and programs that are based on opinion or on the limited research base. Humphrey and Wechsler's (2005) research describe in detail seven programs to understand who participates in alternative certification programs and what learning opportunities the programs provide. The authors test proponents and opponents assumptions about alternative certification against national data and data from the seven programs.

None of the research on alternative certification tells us everything we need to know about the backgrounds of individuals who participate in alternative certification programs. There are many programs, but research studies that do exist are often based on evidence concerning a single program. With that said, researchers generally agree that alternative teacher certification programs are designed to entice persons with various educational, occupational, and life experiences to become teachers (Feistritzer, 1993, 1998; McKibbin \& Ray, 1994; Stoddart, 1995; Wise, 1991). Alternative certification programs are assumed to help diversify the pool of new teachers by attracting more men, minorities, and mature or experienced individuals. Indeed, some programs appear to recruit mid-career switchers, retired military personnel, people of color, and candidates with subject-matter specialties or strong interest in fields with teacher shortages such as mathematics, science, special education, and bilingual education (Wilson, Floden, \& Ferrini-Mundy, 2002; Zeichner \& Shulte, 2001). Research published more than a decade ago found that the New Jersey Provisional Teacher Program and the Los Angeles Paraprofessional Program had higher percentages of males, minorities, and people older than 30 than did traditional programs. In addition, teachers in these alternative programs were more likely to prefer to teach and to continue teaching in urban areas and were less likely to see innercity students as culturally deficient as traditionally prepared teachers (Stoddart, 1995).

Research findings about the academic strengths of teachers who enter the profession through an alternative certification program are inconsistent. Zeichner and Schulte (2001) describe divergent findings in the studies they reviewed comparing National Teacher Examination scores of participants in single programs. In some cases, alternative certification programs require higher grade point averages for admissions than do traditional programs.

Opponents of alternative certification paint a far less rosy picture. Some view alternative certification as merely a mechanism for managing the inevitable teacher shortages in a marketdriven system. They argue that quality is sacrificed when a program's primary purpose revolves around quantity issues. Alternative certification, the opponents maintain, provides a supply-side safety valve that allows unprepared individuals who have met minimal requirements to cover shortages in specific disciplines or in hard-to-staff schools. Other critics of alternative certification, referring to the high attrition rates among this group, question the participants' commitment to teaching. They see some alternative route teachers as temporary workers, using teaching as a bridge over a sluggish economy or as brief stop on the way to another career. Because minority teachers are more likely to pursue an alternative route than nonminority teachers, they assume, others have argued that alternative routes discriminate against minorities, offering them a lower quality preparation and the most challenging positions in the most difficult schools. As this argument goes, the neediest students in the most troubled schools end up with the least prepared teachers; both teachers and students are thus poorly served (Humphrey \& Wechsler, n.d.).

Darling-Hammond, Holtzman, Gatlin, and Heilig (2005) devised a study about the recent debates of teacher education and whether some candidates with strong liberal arts backgrounds might be as effective as teacher education graduates. This study examined these questions with a large student level data set from Houston, Texas that linked student characteristics and achievement with data about their teachers' certification status, experience, and degree levels from 1995-2002. The study examined the question of how teacher preparation and certification influence teacher effectiveness for both Teach For America and other teachers. A newly constructed data set from Houston, Texas allowed the authors to link detailed certification data on teachers to background and achievement data on students, classrooms, and schools 
for 132,071 students who were in fourth and/or fifth grade from the 1996-1997 school year through the 2001-2002 school, and their 4,408 teachers. The TAAS, the SAT-9, and the Aprenda were used as forms to test student achievement. The authors found that, relative to teachers with standard certification, uncertified teachers and those in most other nonstandard certification categories generally had negative effects on student achievement, after controlling student characteristics and prior achievement, as well as teacher experience and degrees.

Gatlin (2008) maintains that there is no empirical evidence that education schools do a better job of preparing teachers or that required professional education coursework increases student achievement. In many states, licensure requirements call for excessive amounts of coursework for new teachers, often virtually equivalent to earning a master's degree. Given the prevailing negative attitude about the current state of teacher preparation programs, both traditional and alternative, it seems appropriate to consider a new paradigm for teacher preparation in the 21 st century.

\section{Teacher Preparation and Student Achievement}

Teachers who have had formal preparation have been found to be better able to use teaching strategies that respond to students' needs and learning styles and that encourage higher order learning. In addition to the ability to create and adapt instructional strategies, strong research support has linked student learning to variables such as teacher clarity, enthusiasm, task-oriented behavior, variability of lesson approaches, and student opportunity to learn criterion material. Teachers' abilities to structure material, ask higher order questions, use student ideas, and probe student comments have also been found to be important variables in what students learn. Teacher preparation programs hope to foster the following characters in a teaching candidate: verbal ability, adaptability and creativity, subject matter knowledge, understanding of teaching and learning, specific teaching skills, and experience in the classroom.

All of these qualities ensure student learning (Darling-Hammond, 2002).

\section{Alternative Certification and Student Achievement}

Nearly all alternative certification programs lower the cost of becoming a teacher, either by reducing the requirements that teachers must fulfill or by allowing teachers to complete requirements while earning a salary as a teacher, or both. Much of alternative certification is focused on attracting people into teaching that did not major in education and might never have been interested in doing so. Some alternative certification programs have been able to recruit teachers with stronger qualifications than those of traditionally prepared teachers. For instance, in 2003 Teach for America (TFA) had 16,000 applicants for 1,800 available slots and was therefore able to be highly selective in terms of teacher qualifications. Teachers recruited in recent years through alternative certification routes tend to have higher test scores that substantially exceed those of teachers from traditional preparation programs. TFA strongly emphasizes recruitment and selection, and their teachers have better general qualifications, but receive substantially less pre-teaching preparation to teach. Thus, these findings may mean that the higher general qualifications of TFA initially offset the more substantial preparation of teachers following the traditional route (Boyd, Goldhaber, Lankford, \& Wyckoff, 2007).

\section{Traditional Certification Programs and Student Achievement}

An important component of virtually all certification and traditional teacher preparation programs is training in pedagogy. Most traditional teacher preparation programs contain multiple courses on aspects of pedagogy. Nearly all routes into teaching include some field experience, like student teaching, where pedagogical skills may be learned and practiced. The first years of teaching provide important lessons on what works. Identifying the best way to prepare teachers to convey subject knowledge to various student audiences is complex and a matter of some dispute. Research examining how students learn, together with the frequently replicated empirical observation that teachers' effectiveness improves over the first few years of their careers, offers at least indirect evidence that pedagogy is important. Pedagogy covers a number of distinct areas; it should be possible to distinguish the various aspects of pedagogy by identifying the relationship of subscores on pedagogy exams or of specific coursework to student achievement (Boyd, Goldhaber, Lankford, \& Wyckoff, 2007).

\section{Summary, Recommendations, and Conclusions}

In 1988, the National Center of Education Statistics published a report stating that 1.65 million teachers were to be hired within the decade of the 1990s. They estimated that of this figure 3 out of 5 teachers would be people not originally choosing teaching as a career (Boyd, 2007). A more current study shows that by 1996-97, 31 percent of the 1992-93 graduates who had taught in public schools had not prepared to teach as an undergraduate. Thus, a significant number of novice teachers made the decision to teach after obtaining their initial degree. More recent data indicates that more than one-fourth of teachers enter the profession without having fully met state licensing standards. Finally, it should be noted that according to the January 13, 2000 edition of Education Week, 40 states offer alternate routes for people who have degrees in subjects other than education, and an estimated 80,000 people have been certified through alternate pathways (Bradshaw, 1998).

The research supports the propositions that alternative routes of certification and traditional routes of certification are both effective in student achievement in regards to reading achievement. In the area of teacher preparation, substantial evidence suggests that general graduate preparation does little to improve student performance. Subject matter pedagogy may improve student achievement, but no evidence exists on most other aspects of pedagogy. Nor is there evidence that teacher field experiences affect student outcomes, although most teachers and other close observers see a strong link between the two. Further study is needed to note whether, administrative support and classroom management play a part in the achievement of the students. 


\section{WORKS CITED}

[1].Au, W. (2004, Fall). No Child Left Untested: The NCLB Zone. Retrieved June 19, 2008, from Rethinking Schools Online: http://www.rethinkingschools.org/archive/19_01/nclb191.shtml

[2].Boyd, G. L. (2007, Spring). The Effect of Certification and Preparation on Teacher Quality. Retrieve June 19, 2008, from www.futureofchildren.org: http://www.futureofchildren.org/usr_doc/7_03.pdf

[3].Boyd, D., Grossman, P., Lankford, H., Loeb, S., \& Wyckoff, J. (2006). How changes in entry requirements alter the teacher workforce and affect student achievement. Education Finance \& Policy, 1 (2); 176-216.

[4].Bradshaw, L. (1998). Policy, Politics, and Contradictions of Alternative Teacher Certification. San Diego: ERIC.

[5].Darling-Hammond, L., Holtzman, D. J., Gatlin, S. J., \& Heilig, J. V. (2005). Does teacher preparation matter? Evidence about Teacher certification, Teach for America, and Teacher Effectiveness. Education Policy Analysis Archives, 13(42). Retrieved [December 2, 2008] from http://epaa.asu.edu/epaa/v13n42

[6].Darling-Hammond, L. (Ed). (1994). Professional development schools: Schools for developing a profession. New York: Teachers College Press.

[7].Darling-Hammond, L. (2002). Research and Rhetoric on Teacher Certification: A Response to "Teacher Certification Reconsidered. ERIC Clearinghouse on Assessment and Evaluation.

[8].Feistritzer, C.E., and D.T. Chester. Alternative Teacher Certification: A State-by-State Analysis. Washington, DC: National Center for Education Information, 2002.

[9].Finn, C.E., Jr. (1999). Foreword. In M. Kanstoroom \& C. E. Finn, Jr. (Eds.), Better teachers, better schools (pp. vvii). Washington, DC: Thomas B. Fordham Foundation.

[10]. Gatlin, D. Thinking Outside of the University. Retrieved December 2, 2008 from Innovation in Alternative Certification. http://www.americanprogress.org/issues/2008/04/pdf/alternative_certification.pdf

[11]. Hawley, W. 1990. "The Theory and Practice of Alternative Certification: Implications for the Improvement of Teaching." Peabody Journal of Education 67(Spring): 3-34.

[12]. Hess, F. M. 2001. Tear Down this Wall: The Case for a Radical Overhaul of Teacher Certification. Washington, DC: Progressive Policy Institute.

[13]. Humprey, W. \& Wechsler, M. \& Heather, H. (2005). CHARACTERISTICS OF EFFECTIVE ALTERNATIVE TEACHER CERTIFICATION PROGRAMS. SRI International.

[14]. Mayer, Daniel P., Paul T. Decker, Steven Glazerman, Timothy W. Silva. 2003. "Identifying Alternative Certification Program for an Impact Evaluation of Teacher Preparation.” 8940-400. Washington, DC:Mathematica Policy Research, Inc. (April). http://www.mathematica-mpr.com/PDFs/identify.pdf

[15]. McKibbin, M., \& Ray, L. (1994). A Guide for Alternative Certification Program Improvement. The Educational Forum, 58, 201-208.

[16]. No Child Left Behind Toolkit for Teachers (2004). Retrieved on August 21, 2018 from http://www2.ed.gov/teachers/nclbguide/nclb-teachers-toolkit.pdf

[17]. Stoddart, T., \& Floden, R. E. (1995). Traditional and alternate routes to teacher certification: Issues, assumptions, and misconceptions. Issue Paper 25-2, \#48824-1034, from the National Center for Research on Teacher Learning, ERIC Document, ED 383697.

[18]. Unmuth, K. (2008, June 22). State pushes for stricter rules on alternative certification teacher programs. Retrieved June 23, 2008, from dallasnews.com: http://www.dallasnews.com/sharedcontent/dws/dn/latestnews/stories/062208dnmetaltcertbattle.4 0f41b5.html

[19]. White, D. (n.d.) Pros \& Cons of the No Child Left Behind Act. Retrieved August 21,2018 from http://usliberals.about.com/od/education/i/NCLBProsCons.htm

[20]. Wilson, S.M., Floden, R.E. \& Ferrini-Mundy, J. (2002). Teacher preparation research: An insider's view from the outside. Journal of Teacher Education, 53(3), 190-240. Download the article at http://depts.washington.edu/ctpmail/Reports.html\#TeacherPrep.

[21]. Wise, A. E., and L. Darling-Hammond (1991). "Alternative Certification Is an Oxymoron." Education Week September 4.

[22]. Zeichner, K. M. and A. K. Schulte (2001). "What we know and don't know from peer-reviewed research about alternative teacher certification programs." Journal of Teacher Education 52(4): 266-282. 